\title{
Spleen rupture due to brucellosis
}

\author{
Orhan Yağmurkaya ${ }^{1}$ (D), Serhat Oğuz² (D), Eyüp Kahya ${ }^{3}$ (D), Hüseyin Aksoy ${ }^{4}$ (D), Doğan Albayrak² (D), Tamer Sağıroğlu² (iD \\ ${ }^{1}$ Clinic of General Surgery, Sakarya University Training and Research Hospital, Sakarya, Turkey \\ 2 Department of General Surgery, Trakya University Faculty of Medicine, Edirne, Turkey \\ ${ }^{3}$ Clinic of General Surgery, Edirne Public Hospital, Edirne, Turkey \\ ${ }^{4}$ Clinic of General Surgery, Yozgat Public Hospital, Yozgat, Turkey
}

\begin{abstract}
Brucellosis is a common zoonotic infection worldwide; it is caused by infection with the bacterial species Brucella and leads to severe diseases in humans and animals. In Turkey, this bacterial species has not been completely eradicated and is commonly found in animals (such as goats or sheep). Brucellosis can lead to various symptoms, affect multiple systems, and cause splenomegaly in the case of spleen involvement. In contrast to traumatic spleen ruptures, spontaneous spleen ruptures are rare and most commonly occur because of infectious causes. A 52-year-old man was treated at our infectious diseases clinic for Brucella endocarditis. Due to sudden abdominal pain, nausea, vomiting, and vertigo, the patient was evaluated by our team of doctors at the same clinic. The patient had widespread sensitivity in the abdominal region, as well as defense and rebound symptoms. Emergency abdominal tomography revealed a ruptured spleen and widespread hemorrhagic fluid in the abdomen. Exploration revealed multiple ruptures in the spleen capsule. The patient underwent splenectomy and did not experience any complications during the postoperative period. Spontaneous spleen rupture is a rare clinical condition that should be considered in patients who are hospitalized at internal medicine clinics for infectious, hematogenic, and metabolic causes, as well as in those who have sudden abdominal pain and hypovolemia.
\end{abstract}

Keywords: Brucella, spontaneous spleen rupture, hemorrhagic shock

Cite this article as: Yağmurkaya O, Oğuz S, Kahya E, Aksoy $H$, Albayrak D, SağıroğluT. Spleen rupture due to brucellosis. Turk J Surg 2021; 37 (1): 73-75.

Corresponding Author Orhan Yağmurkaya

E-mail: orhanyagmurkaya@gmail.com

Received: 05.08.2015

Accepted: 03.11.2015

Available Online Date: 22.03 .2021

@ Copyright 2021 by Turkish Surgical Society Available online at www.turkjsurg.com

DOI: $10.47717 /$ turkjsurg.2021.3295

\section{INTRODUCTION}

Brucellosis, caused by infection with the bacterial species Brucella, is a common zoonosis worldwide that can cause severe diseases in humans and animals. Brucellosis can lead to various symptoms, affect multiple systems, and cause splenomegaly in the case of spleen involvement. Due to multiple system involvement, the symptoms and manifestations of brucellosis are generally nonspecific. However, non-specific symptoms, including fever, fatigue, and sweating are common, and hepatosplenomegaly is frequently seen.

The spleen is an immunological organ affected by hematological and non-hematological diseases. Spleen rupture usually occurs because of blunt abdominal trauma. In contrast to traumatic spleen ruptures, spontaneous spleen ruptures are rare and most commonly occur due to infectious causes. Mortality can occur in this patient group due to a delay in diagnosis and treatment (1).

This paper aimed to present a case of spontaneous spleen rupture that occurred secondary to brucellosis but is rarely reported in the literature.

\section{CASE REPORT}

A 52-year-old man was treated at our infectious diseases clinic for Brucella endocarditis. Due to sudden abdominal pain, nausea, vomiting, and vertigo, the patient was evaluated by our team of doctors at the same clinic. The patient had no history of trauma. First evaluation revealed that his blood pressure was $70 / 50 \mathrm{mmHg}$ and his heart rate was 112 beats/minute. The patient had widespread sensitivity in the abdominal region, and defense and rebound symptoms. Hemoglobin level was $8.6 \mathrm{~g} / \mathrm{dl}$, and other laboratory parameters were normal. Emergency abdominal tomography revealed a ruptured spleen and widespread hemorrhagic fluid in the abdomen (Figures 1 and 2). The patient underwent emergency surgery. A median incision was used to enter the abdomen. Exploration revealed multiple ruptures in 


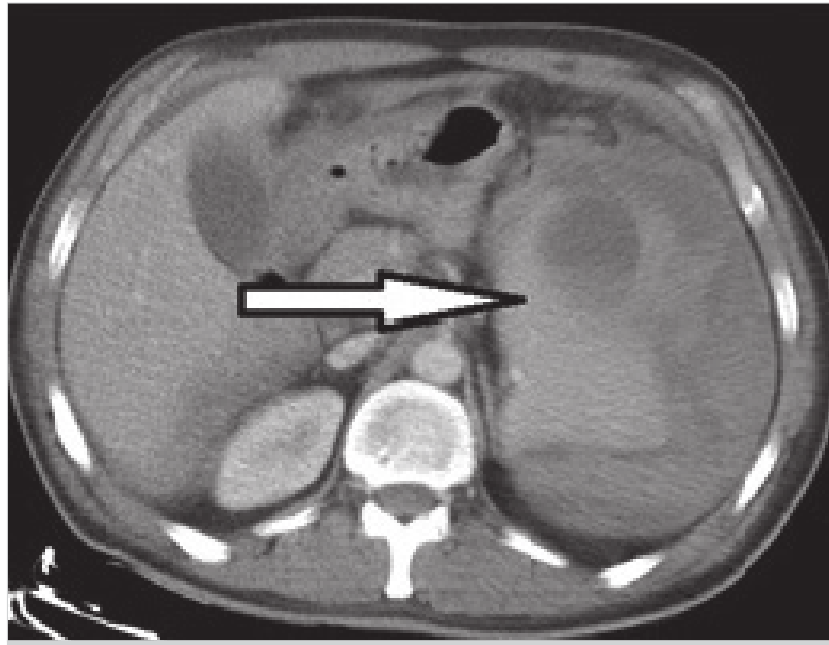

Figure 1. Ruptured spleen (white arrow).

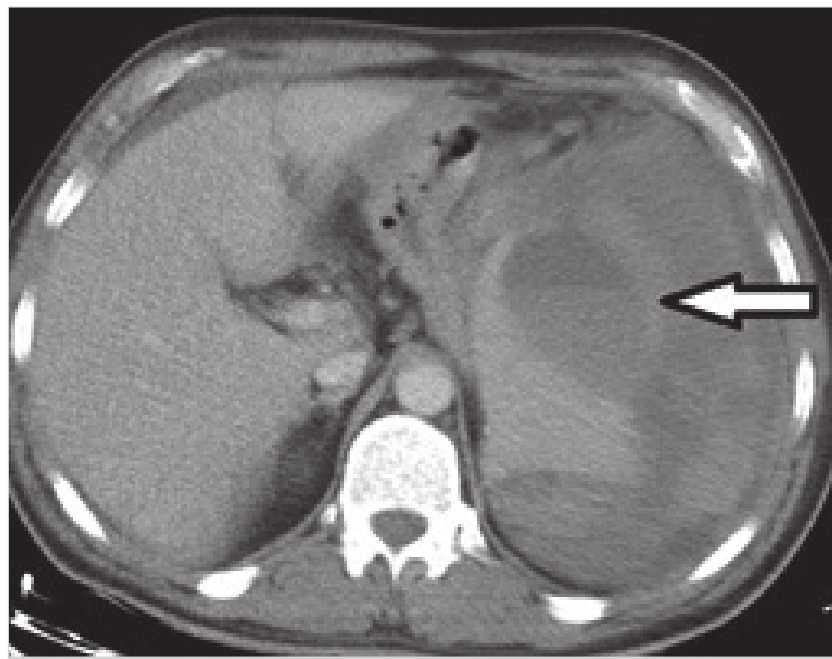

Figure 2. Hemorrhagic fluid (White arrow).

the spleen capsule and approximately $1000 \mathrm{cc}$ of hemorrhagic fluid. The patient underwent splenectomy and experienced no complications during the postoperative period. The patient was then transferred to the infectious diseases department to continue medical treatment.

\section{DISCUSSION}

Brucellosis is a zoonotic infection that has not been completely eradicated, and it is commonly found in animals (such as goats or sheep) in Turkey. Transmission from animals to humans usually occurs by direct contact between the secretions of infected animals and the skin, the consumption of unpasteurized milk and dairy products, inhalation of infected aerosols, and conjunctival contact. Despite the common involvement of lymphoreticular system organs, particularly the liver, bone marrow, spleen, and lymph nodes, Brucella infections can also involve different organs and tissues, including the heart, genitourinary system, central nervous system, and joints $(2,3)$.
Due to multiple system involvement, the symptoms and manifestations are generally nonspecific. However, non-specific symptoms, including fever, fatigue, and sweating are common, and hepatosplenomegaly is frequently seen.

Symptomatology studies in Turkey have revealed that the major complaints are fever (43-83\%), sweating (65-78\%), night sweating (69\%), lower back pain (22-33\%), headache (28-44\%), lack of appetite (34-53\%), joint pain (20-76\%), muscle pain (56\%), fatigue (14-81\%), difficulty walking (11-18\%), clouding of consciousness (6\%), weight loss (2-36\%), and numbness in the arms (2\%) (4).

The first case of spontaneous spleen rupture was published by Atkinson in 1874 (5). Spontaneous spleen rupture constitutes $1 \%$ of all spleen ruptures (6). While the exact cause of spontaneous spleen rupture remains unknown, three mechanisms are considered to play a role in its disease pathogenesis: an increase in intrasplenic pressure due to congestion and hyperplasia of the cells; an increase in intra-abdominal pressure during physiological activities and compression of the spleen by the abdominal muscles; and blockage of vascular structures due to reticuloendothelial hyperplasia (eg., thrombosis, infarction). Interstitial and subcapsular mechanisms can emerge depending on these mechanisms $(7,8)$. Spontaneous spleen rupture can result from infectious causes (malaria, infectious mononucleosis, syphilis, and Brucella infection), hematological causes (anticoagulant treatment, lymphoma, and leukemia), metabolic causes (amyloidosis and sarcoidosis), local causes (splenic vein thrombosis and pancreatitis), and other causes (vomiting and coughing) (9).

Given the high mortality rate of spleen rupture, patients must be diagnosed and treated immediately. Initially, patients have pain in the left upper quadrant, which is followed by sensitivity, and rigidity. Vertigo, vomiting, hypotension, tachycardia, and oliguria can accompany abdominal symptoms, depending on the degree of hemorrhagic shock. Hemorrhagic shock can develop in more than half of patients, if there is no timely intervention (10).

Radiological examination (eg., ultrasonography) can reveal an enlarged, displaced, double-countered spleen, as well as intraperitoneal bleeding. Abdominal tomography can help achieve a definitive diagnosis and enable the detection of hypodense/ hyperdense foci, together with intracapsular, perirenal, and intraperitoneal fluid. Additionally, computed tomography can be used to grade the rupture (11). Decisions about treatment depend on the hemodynamic stability of the patient, level of bleeding in the peritoneal space, blood transfusion, and organ damage score.

\section{CONCLUSION}

Spontaneous spleen rupture is a rare clinical condition that should be considered in patients hospitalized in internal medicine clinics for infectious, hematogenic, and metabolic causes, and in those with sudden abdominal pain and hypovolemia. 
Informed Consent: Written informed consent was obtained from patient who participated in this case.

Peer-review: Externally peer-reviewed.

Author Contributions: Concept - O.Y., S.O., T.S.; Design - O.Y., E.K., H.A., D.A.; Supervision - O.Y., D.A., T.S.; Materials - O.Y, H.A., E.K., S .O.; Data Collection and/or Processing - O.Y., S.O., E.K.; Analysis and/or Interpretation - O.Y., D.A., T. A; Literature Search -O.Y., H.A.; Writing Manuscript - O.Y., D.A.; Critical Reviews - O.Y., D.A., T.S

Conflict of Interest: No conflict of interest was declared by the authors.

Financial Disclosure: The authors declared that this study has received no financial support.

\section{REFERENCES}

1. Wehbe E, Raffi S, Osborne D. Spontaneous splenic rupture precipitated by cough: a case report and a review of the literature. Scand J Gastroenterol 2008; 8(5): 634-7. [CrossRef]

2. Young EJ. Brucella Species. In: Mandell GL, Douglas RG, Bennett JE, editors. Principles and Practice of Infectious Diseases. $6^{\text {th }}$ ed. Philadelphia: Churchill Livingstone; 2005. p.2670-3. [CrossRef]

3. BlackFT. Brucellosis. In: Cohen J, Powderly W, editors. Infectious diseases. $2^{\text {nd }}$ ed. Edinburgh: Elsevier Limited; 2004. 1665-8. [CrossRef]
4. Vardar I, Türker N, Cebelli I, Kölgeli O, Uçdu M, Ayaydın A. Bruselloz: 120 erişkin olgunun klinik, laboratuar ve tedavi özelliklerinin değerlendirilmesi. Izmir Atatürk Eğitim Hastanesi Tip Dergisi 2002; 40 (1): 67-70. [CrossRef]

5. Badenoch DF, Maurice HD, Gilmore OJ. Spontaneous rupture of a normal spleen. J R Coll Surg Edinb 1985; 30(5): 326-7. [CrossRef]

6. Acar YA, Dedeoğlu E, Çevik E, Çınar O, Arslan D, Kesim E, et al. Spontaneous rupture of spleen as a rare cause of abdominal pain. Eur J Surg Sci 2010; 1: 27-9. [CrossRef]

7. Zieren J, Paul M, Scharfenberg M, Muller JM. The spontaneous splenic rupture as first manifestation of mantle cell lymphoma, a dangerous rarity. Am J Emerg Med 2004; 22(7): 629-31. [CrossRef]

8. Yağmur Y, Kara IH, Aldemir M, Büyükbayram H, Taçyıldız IH, Keleş C. Spontaneous rupture of malarial spleen: two case reports and review of literature. Crit Care 2000; 4(5): 309-13. [CrossRef]

9. Debnath $D$, Valerio D. Atraumatic rupture of the spleen in adults. JR Coll Surg Edinb 2002; 47(1): 435-7. [CrossRef]

10. Orloff MJ, Peskin GW. Spontaneous rupture of the normal spleen: a surgical enigma. Int Abs Surg 1958; 106(1): 1-11. [CrossRef]

11. Crate ID, Payne MJ. Is the diagnosis of spontaneous rupture of a normal spleen valid? J R Army Med Corps 1991; 137(1): 50-1. [CrossRef]

\section{OLGU SUNUMU-ÖZET}

Turk J Surg 2021; 37 (1): 73-75

\section{Bruselloza bağlı dalak rüptürü}

Orhan Yağmurkaya ${ }^{1}$, Serhat Oğuz ${ }^{2}$, Eyüp Kahya ${ }^{3}$, Hüseyin Aksoy ${ }^{4}$, Doğan Albayrak ${ }^{2}$, Tamer Sağıroğlu²

${ }^{1}$ Sakarya Üniversitesi Eğitim ve Araştırma Hastanesi, Genel Cerrahi Kliniği, Sakarya, Türkiye

${ }^{2}$ Trakya Üniversitesi Tıp Fakültesi, Genel Cerrahi Anabilim Dalı, Edirne, Türkiye

${ }^{3}$ Edirne Devlet Hastanesi, Genel Cerrahi Kliniği, Edirne, Türkiye

${ }^{4}$ Yozgat Devlet Hastanesi, Genel Cerrahi Kliniği, Yozgat, Türkiye

\section{ÖZET}

Brusella, dünyada yaygın olarak görülen bir zoonoz olup, insanlarda ve hayvanlarda ciddi hastalık yapabilme kapasitesine sahiptir. Bruselloz dünyadan tam olarak eradike edilememiş, özellikle ülkemizde keçi ve koyun gibi hayvanlarda yaygın olarak bulunan zoonotik bir enfeksiyondur. Birçok sistemi etkileyebilen değişik semptom ve bulgulara sebep olan brusella, dalakta tutuluma bağlı olarak splenomegaliye de neden olabilmektedir. Spontan dalak rüptürleri ise travma dalak rüptürlerinin aksine nadir görülüp, en sık enfeksiyöz nedenlere bağlı olarak gerçekleşmektedir. Elli iki yaşında erkek hasta brusella endokarditi tanısıyla enfeksiyon hastalıkları kliniğinde yatmakta iken, ani başlayan karın ağrısı, bulantı, kusma ve baş dönmesi şikayeti ile olması üzerine yattığı serviste tarafımızdan değerlendirildi. Karında yaygın hassasiyet, defans ve rebound bulguları mevcuttu. Hastaya acil olarak çekilen karın tomografisinde; dalağın rüptüre ve karın içinde yaygın hemorajik mayi olduğu görüldü. Eksplorasyonda dalak kapsülünde birden fazla alanda yırtık olduğu görüldü. Splenektomi uygulanan ve hastamız postoperatif dönemde sorunsuz takip edildi. Bizim olgumuzda olduğu gibi dahili kliniklerde enfeksiyöz, hematojenik ve metabolik sebeplerle yatan hastalarda ani gelişen karın ağrısı ve hipovolemi durumunda, spontan dalak rüptürü akılda bulundurulması gereken ve nadir klinik bir durumdur.

Anahtar Kelimeler: Brusella, spontan dalak rüptürü, hemorojik şok

Doi: $10.47717 /$ turkjsurg.2021.3295 